Historic, Archive Document

Do not assume content reflects current scientific knowledge, policies, or practices. 



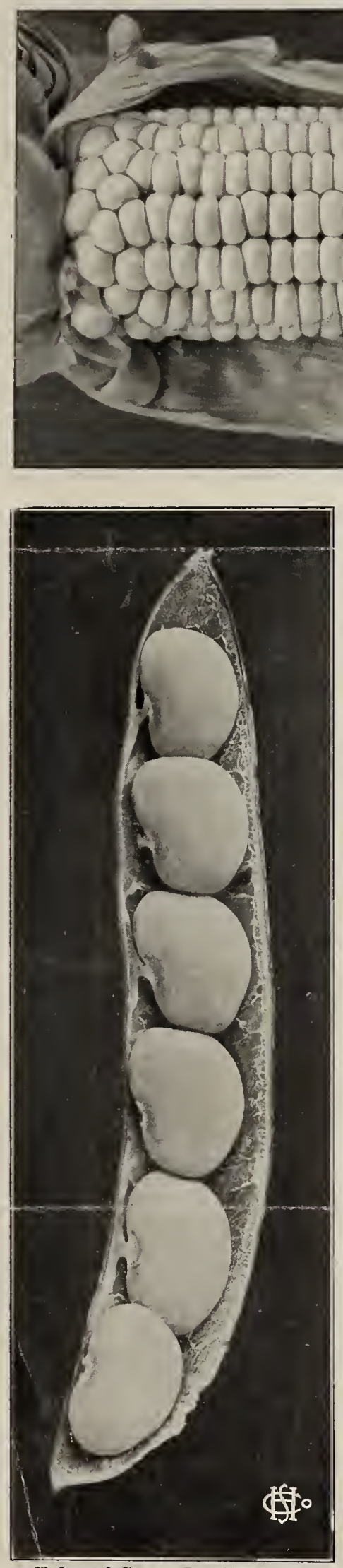

\section{Holmes' Novelties FOR 1910}

\section{To the Trade}

TIV ITH a feeling of confidence, we pre行 110 sent on the following leaflet two sterling novelties. "Tested," under careful scrutiny of expert growers they have "not been found wanting."

Not only will they stand alone upon their own merit, but they will be conceded to have but few peers and no superiors when you, as have we, shall have tried them out.

The illustrations on the circular are our own design and accurate photographic reproductions.

HOLMES' SEED CO., No. 9 North Market Square, Harrisburg, Pa. 


\section{HOLMES’ DELICIOUS EARLY SWEET CORN}

An Entirely New and Distinct Variety-Ready for Market Sixty-five Days From
Date of Planting. Without Exception the Most Delicious Early Sweet Corn

Fully equals our Premo in size, twelve rows, among the first in the market. Stalks grow from 5 to 6 feet high, and in the entire crop of several acres this year we found the ears

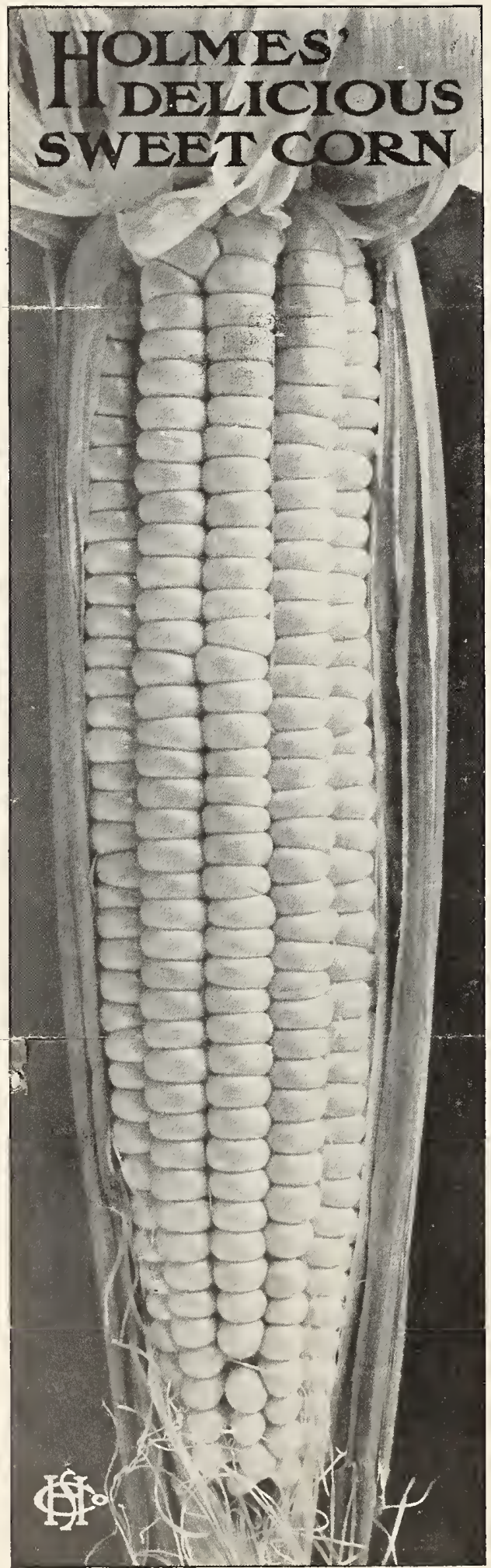
to be absolutely free from smut. It is a drought-proof Corn, which has not only been proven by our own test, but the few testimonials given below bear us out in this. The crop which we grew this year, although through a drought, has done exceedingly well.

We can truthfully say in offering " Holmes' Delicious Sweet Corn" that we do so knowing it will grow in public favor, the same as our many other novelties which we have introduced.

The private gardener is always on the lookout for something superior to anything he has had before-the 'Holmes' Delicious" meets this requirement.

The market-gardener is also always on the lookout for something extremely early-this also meets his wants.

The farmer, as well as the private and market-gardener, is just as eager to secure a good article, and to him we can truly say: the " Holmes' Delicious" meets his requirements.

From personal observation of our crop this year we describe the Corn as follows: The stalks grow about 5 to 6 feet, and in the entire crop that we grew of several acres we did not find a single ear that was not absolutely free from smut. It is one of the hardiest of Corns that we know of, and can be planted at the same time as the Premo or Adams' Extra-Early. Each stalk bears from two to three well-developed ears. Now we took particular notice to this one fact, that each stalk had at least two

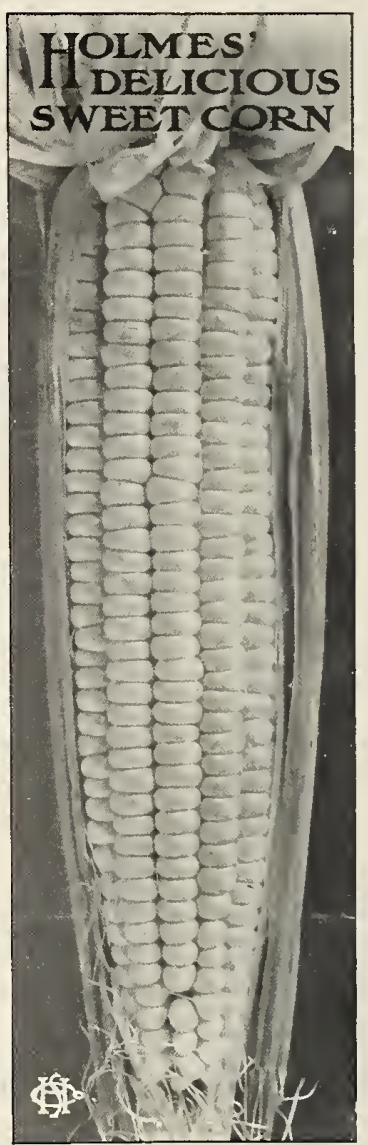
ears that were marketable, - not as the usual growth of Corn: that is, one small and one large ear, but both grew large and in many instances three well-developed ears were on the stall:.

The engraving also shows one stalk with four fully developed ears on same; hence this proves that the Corn is not only all we claim for it, but is very prolific.

The testimonials herewith are, as you can see, from reliable sources of gentlemen of high moral character and standing. 


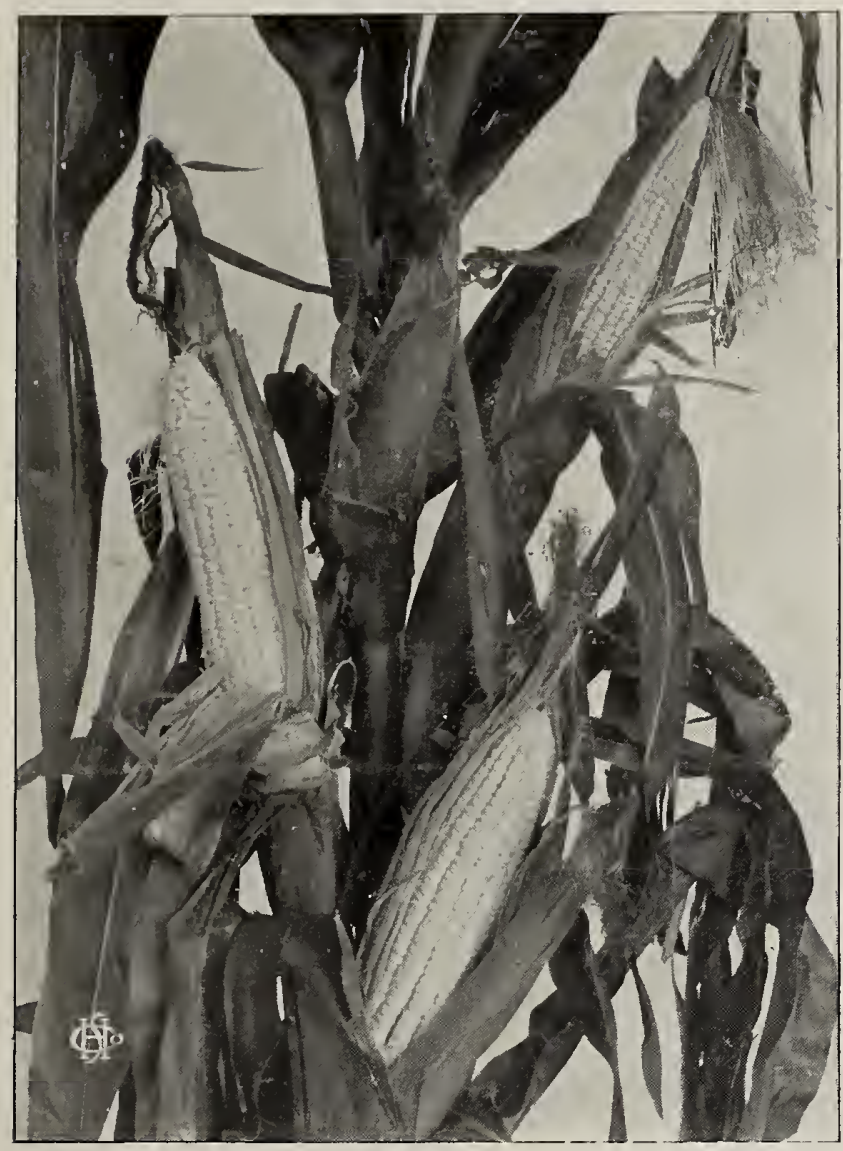

\section{What Our Customers Say}

Genllemen: Referring to the Corn obtained from me a year ago would say my honest opinion is that it is the most delicious Corn I have ever eaten. It is very tender, juicy and sweet, and has a flavor most pleasing to the palate It ranks far ahead of any of the varieties that have yet come befure my notice. I have given this Corn to a great many of my friends, and they have all pronounced it superior to anything they have ever eaten. This Corn originated (as far as we know) with one Mr. DeHart, our next-door neighbor, about sixty years ago, and he gave us some of his seed Corn so that our own Corn and his would be alike, to prevent his from mixing-he thought so much of his prize that he never allowed any of the seed to fall into any other hands but his own and ours, - and during all these vears of cultivation we have continued to improve this Corn through cartful selection each and every year. We have been very particular to keep it pure, and we are very glad that you are the possessors of this truly delicious Corn.-IVM K. HARRIS.

We planted the Holmes' Delicious Corn in May and ate same in July-it is an exceedingly early and a very fine Corn of the finest flavor.-H. A. HiLl, Fleetwood, Pa.

Gentlemen: In regard to your Delicious Sweet Corn: I planted it quite late, by so doing it would be less likely to become mixed through the tassel of other kinds, but the season was dry on the average and the test is not a fair one but every kemel promptly came up and grew rapidly. I made twenty hills, two kernels to the hill, 3 feet apart. Every hill and kernel came up and grew finely, was at least .5 feet high. On almost every hill there were two ears of corn and quite a number liad three ears. I have only to sav. I love it, as I believe it is extremely early and sweet, good shape and gond size, and a grand acquisition I noticed its hardiness, good shape and healthy appearance. Yours for success, J. W. BAKER, Fiskilwa, Ill., Sept. $23,1909$.

\section{A TRIAL GROUND REPORT FROM FORDHOOK FARMS}

Gentlemen: Replying to your letter of recent date we have pleasure in enclosing herewith our reports on the Sweet Corn and Lima Beans sent us for trial and trust these will meet with your ap

No. 1056 S w e et Corn,

Early - - Planted May 15 , noted August 25 , good stand. Height of plant $51 / 2$ feet, produced usually in pairs Ears of medium size and slender, measuring $6 \frac{1}{2}$ inches long ; ro-rowed, kernels white $1 / 4-$ inch deep and $1 / 4$-inch broad, cob white 7 -10-inch in diameter; flavor superb. Ears well filled.

No. 707 Bean, Green Prolific Lima.-The Beans can be gathered inclusters of from five to six and are produced continuously from the bottom to the tip of the vines The pods measure $63 / 8$ inches long and $13-16$ inches broad and average five and sometimes six beans to each. The seed, which is flat, measures $13 / 8$ inches long by $13-16$ of an inch wide. The pods are slightly curved. The beans reach maturity in about sixty days from the time the seed is sown. Very truly yours, W. ATLEE BurpeE.

\section{A GROWER'S REPORT OF "HOLMES' DELICIOUS SWEET CORN"}

Gentlemen: Since sending you the samples of Corn which left here on September 15 , we have been using from the same lot, and we find as the Corn got a little older that the quality improved. The Corn seems to have if anything a better flavor, and it is certainly a very fine quality of Siveet Corn. We would like to know how you found the sample, which was sent you, and if all was satisfactory. We are in good hopes now that our late piece will ripen, but it will have to have considerable good weather yet. Yous truly, Constock, FERRE \& Co., per S F. Willard. Pres.

In explanation, last winter Mr. Rust stated he hardly believed we had a Corn better than Premo, Peep-o'-Day and some others. He stated laughingly he would send an order so we could have no chance to fix it up; this we did and were surprised later for him to tell us he had the Corn and would give it a fair test. The results are given below in his letter:

"I desire to express to you the satisfaction I received from your Delicious Sweet Corn, which I ordered from you this past spring. With me it was six days earlier than two other extra-early varieties, and these latter two varieties are considered the earliest of all. Also it is hardier than other early varieties, it withstands the wet and cold soil of a late spring. and can thus be planted a week or ten days ahead of any other corn. You have it named correctly. for in flavor it is delicious." Yours very truly, DAViD 'RUST, Secretary of Pennsylvania Horticultural Societr.

IV Dear Sirs: Your favor of the I7th inst. duly received on my return to the city Mr. Harris undoubtedlv told you the exact truth about the Corn. I never saw its equal for quality and sweetness; the ears are not as large as some others, but fine gonds come in small packages.-C. H. FAHNESTOCK, Cashier Fidelity Trust Co.

\section{DELICIOUS CORN}

The Holmes' Delicious Sweet Corn has an excellent flavor, and I can truly recommend it to any one desiring a good table Corn-DR. G. A. Gorras, Camp Hi!l, Pa.

\section{Wholesale Prices of Holmes' Delicious Corn for 1910}

Bus., $\$ 8 ; 6$ bus., $\$ 42$; 10 bus., $\$ 65 ; 20$ bus. and over at $\$ 5$ per bus. 5 per cent 10 days, net 60 days. With every order of 6 bus. and over electrotypes furnished free.

RETAIL PRICES. Pkt., 15 cts.; pt., 40 cts.; qt., 75 cts., ky mail postpaid. By express or freight, 4 qts., $\$ 2.50$; pk., $\$ 4$; bus., $\$ 15$.

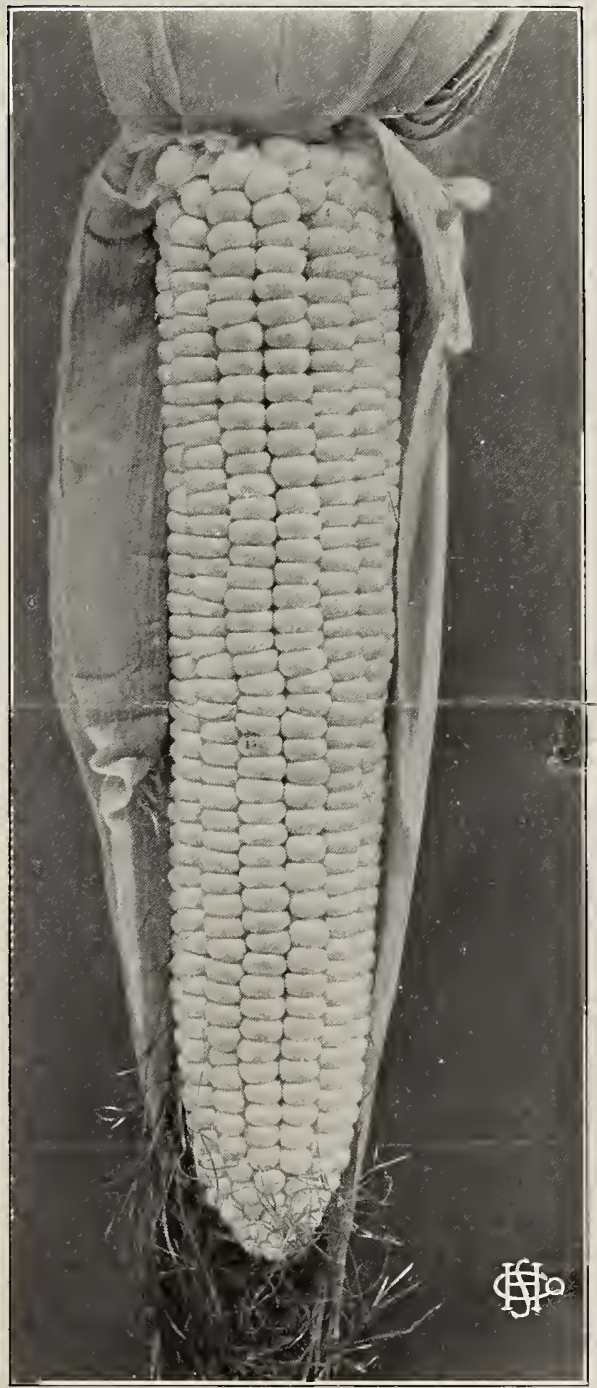




\section{HOLMES'}

\section{POLE LIMA BEAN \\ Grows Green, Keeps Green, and the Only Lima Bean that is Absolutely Green when Dried}

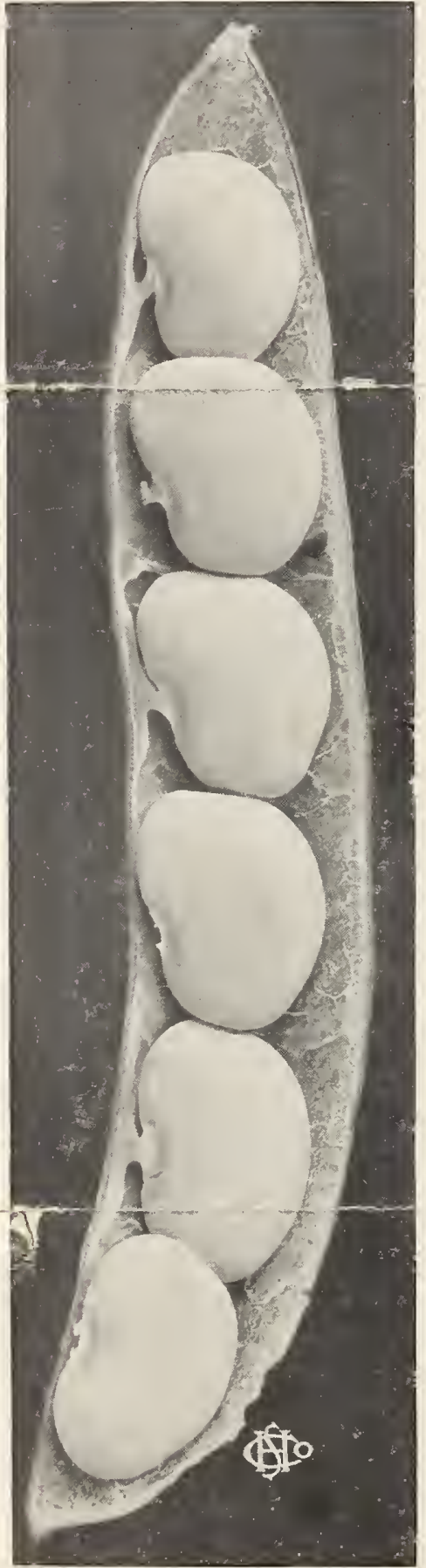

The most productive Pole Lima Bean, as early as the Early Jersey and unquestionably the most prolific of all Pole Limas

Origin. This Pole Lima was originated in Philadelphia over sixty years ago by Mr. Lafferty, a market-gardener, in the "Neck," - that portion of South Philadelphia lying between the Delaware and Schuylkill rivers. Mr. Lafferty was a gardener of renown who made a specialty of growing Lima Beans for family and hotel trade, and being a very careful gardener succeeded in the course of his lifetime in producing this Bean. Through careful selection of the Beans, close observation and long years of application, he finally became known in his locality as the best grower of Lima Beans in the "Neck." He cherished this Lima Bean and was careful to keep it to himself until he died, when his son, Godfrey, brought it to Mr. IVm. K. Harris, the noted florist in Philadelphia, ahout twenty years ago, and he has used his best endeavors to keep it as true as the original type.

What we found out. In our crop, which we grew this year, we find the Bean equals the Early Jersey or any other variety for earliness, and is by far more productive than any other Pole Lima we have ever seen grow. It is not like the Mastodon Lima, which retains only a portion of the green coloring in the dry Bean, but each and every Bean of Holmes' Green Prolific Pole has that Pods. true, distinct, deep green color which insures the color when the Beans are Pods. shelled for market. The large pods hang in clusters of from five to eight, which nlakes them easy to gather, each having five to six Beans in a pod.

\section{WHAT THE GROWERS SAY}

MEssRs. Geo. R. PEDRick \& Sox, who grew this Bean for us this year, write: "The Holmes' Green Prolific Pole Lima' Bean, which we grew for you this past season, was one of the most productive Pole Limas we have ever seen growing, bearing large clusters, six to eight pods, containing five to six perfect formed Beans as large as the king of the Garden or Large White Lima of true dark green color, which has long been sought by many seedsmen, and we believe this is one of the novelties which has come to' stay that has merit. In Havor they are delicious and tender."

THEY ARE MORE THAN A WONDER

Your Holmes' Green Prolific Pole Lima Beans are up o the handle-" they are more than a wonder." I have had exceedingly good results from them, and am very proud of the Green Lima.-Howard C. Griffith, Reinhold's Sta., Pa.

\section{DID REMARKABLY WELL}

From the packet of Green Lima Beans I received from you I succeeded in raising a pint. They did remarkably well considering the terrible drought we have just gone through, and I am more than pleased.-IIRS. A sos E. Gish. Elizabethtown, $\mathrm{Pa}$.

\section{ALL YOU CLAIM FOR IT}

In regard to the novelty, Holmes' Green Prolific Lima Bean, I bought from you last year, the drought was so severe it was impossible to give the Bean a yood test; how ever, I believe the Bean is all you claim for it.-Joun S. IVEAYEr, Glen Mar seed Farms, Kinzer's, Pa.

\section{PRACTICALLY DROUGHT PROOF}

The Holmes' Green Prolific Lima Bean did remark ably well considering the drought we have just passed through. They are very large and of excellent flavor. One remarkable feature is the filling out of the pods. We had no rain for two months, which goes to show that Holmes' Green Prolific Pole Lima Bean is practically drought proof. H. A. Hit. L, Fleetwood, $\mathrm{Pa}$.

\section{Wholesale Prices of Holmes' Green Prolific Pole Lima Beans for 1910}

Single bushel, $\$ 10 ; 6$ bus., $\$ 55 ; 10$ bus. and over at $\$ 8.50$ per bus. Electros furnished free on orders of 6 bushels and over. Terms, 5 per cent 10 days, net 60 days.

RETAIL PRICES, pkt., 15 cts.; pt., 50 cts.; qt., 85 cts., postpaid. By freight or express, 4 qts., \$3; pk., $\$ 5.50$; bus., $\$ 18$.

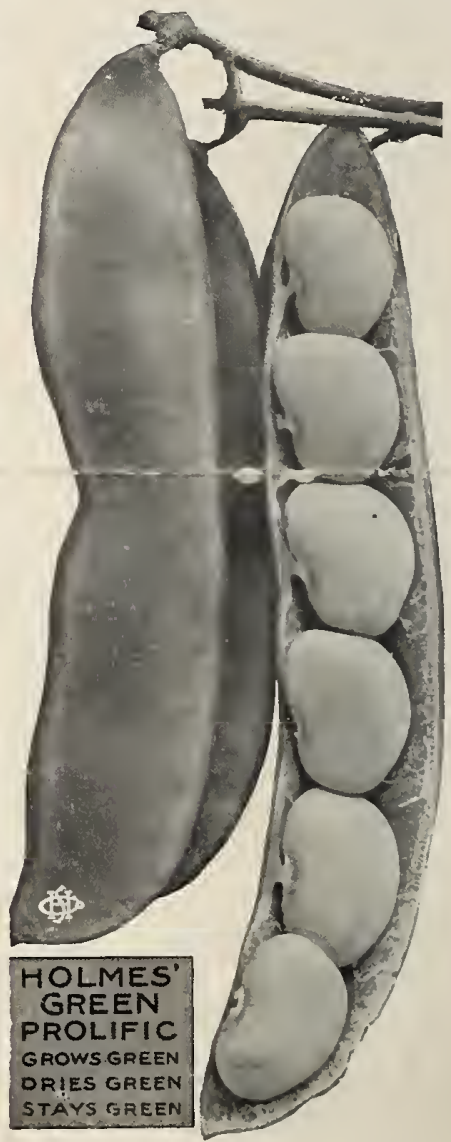

